J. Perinat. Med. 14 (1986) 309

\title{
The effect of maternal smoke exposure on the ultrastructure of fetal peripheral blood vessels in the mouse
}

\author{
Robert C. Kaufmann, Kofi S. Amankwah, and Aruna D. Weberg
}

Division of Maternal Fetal Medicine, Department of Obstetrics and Gynecology, Southern Illinois University School of Medicine, Springfield, Illinois, U.S.A.

\section{Introduction}

The harmful effect of maternal cigarette smoking on the fetus is variable and may result in "only" a decrease in weight or may cause death by abruptio placenta [10]. In adults, smoking causes pathological changes in the cardiovascular system [9]. Some authors have proposed that smoking during pregnancy may also cause pathological changes in the cardiovascular system of the fetus that would increase the risk of heart and peripheral vascular disease in adulthood $[2,4]$. The placenta and umbilical cord vessels of human fetuses whose mothers smoked during pregnancy have been found to contain ultrastructural changes [1-5]. These changes were seen in the fetal vessels that are closest to the point of noxious transfer. This study was done to determine if similar ultrastructural changes could be seen in fetal peripheral vessels far removed from the point of noxious transfer. Because of the relative unavailability of human fetal tissue for ultrastructural study, an animal model of smoking during pregnancy was chosen to carry out this project.

\section{Materials and methods}

All mice in this study were of the C57BL/ $\mathrm{KsJ}-+\mathrm{m} /+\mathrm{m}$ strain obtained from Jackson Laboratory, Bar Harbor, Maine. Female and

\section{Curriculum vitae}

ROBERT C. KaUFMaNN, M.D., born 1951, U.S.A., graduated 1973 B.S. 1976 M.D., from Southern Illinois University School of Medicine, Springfield, Illinois. Certified American Board of Obstetrics and Gynecology. Licensure with State of Illinois. Fellow, American College of Obstetricians and Gyneco-

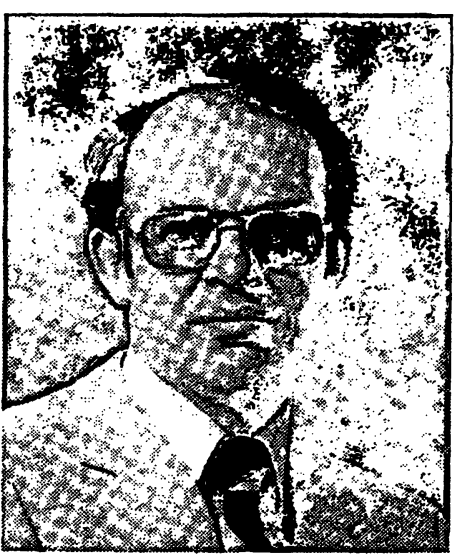
logists. Member of American Medical Association, Society of Perinatal Obstetricians, Illinois State Medical Society, Central Perinatal Association of Illinois, and South Central Illinois Perinatal Consortium. Faculty member since 1980, Assistant Professor, Division of Maternal/ Fetal Medicine, Department of Obstetrics and Gynecology, Southern Illinois University School of Medicine, Springfield, Illinois since 1982.

male, two to three month old mice were placed in a breeding cage and exposed to cigarette smoke by placing their cage in a special smoking chamber (figure 1) similar to that used by YounOsZaI [12]. This specific device was chosen because it employs a regimen of intermittent smoke exposure over a lengthy period of time simulating the effects of smoke in a confined space much like that found in many working environments. Low tar cigarette smoke was 


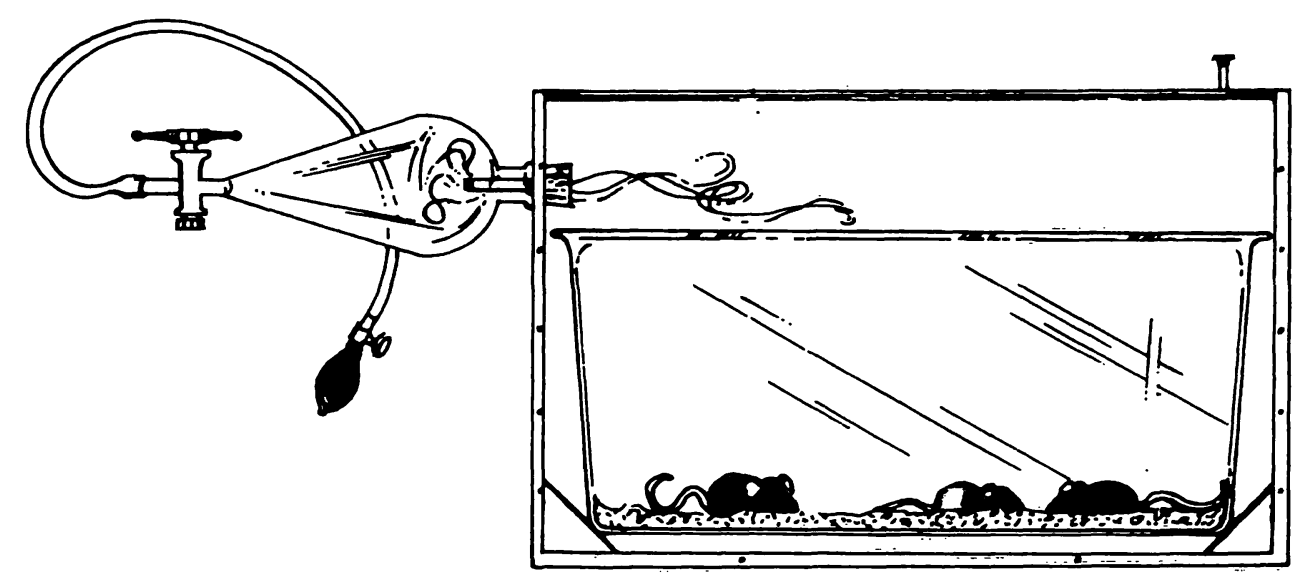

Figure 1. Smoking chamber containing a cage of pregnant mice. The chamber top was covered with a plexiglass lid. A separatory funnel on the side of the box served as a smoking device, holding a cigarette in

blown into the chamber for four minutes, five times daily, except on weekends when it was done three times a day. This method has been shown to produce a carboxyhemoglobin level of approximately $9.0 \%$ which is similar to that found in an adult human smoking one pack of cigarettes per day.

When not being exposed to smoke, the mice were housed in a room with 12 hour light/dark cycle. Similarly caged mice of the same strain were used as control animals, placed in a chamber but not exposed to smoke, and housed in the same room. Both groups of mice had laboratory chow and tap water ad lib for 24 hours/day. The amount of food ingested by both groups was weighed daily. The mice became pregnant and delivered in the same cage. After spontaneous delivery the live pups were weighed. Two pups from the litters of three dams in both the control and study groups were taken for this study, yielding a total of six pups in each group. The remaining pups were used for other studies. Each pup was sacrificed via neck fracture, and the entire pup was immersed in a solution of $2.5 \%$ gluteraldehyde in $0.1 \mathrm{M}$ cacodylate buffer at $\mathrm{pH}$ 7.3. While still under solution, the rear leg muscles were dissected free, sliced, and immersed in the same preservative for four to five hours. They were then placed in fresh $2.5 \%$ gluteraldehyde mixture overnight. The tissues were postfixed in osmium place by means of one-holed stop cock. The other end of the funnel was attached to a tube ending in a rubber bulb which was used to force the cigarette smoke into the chamber.

ferrocyanide and en-block stained with uranyl acetate in a graded series of alcohol. The tissues were infiltrated with and embedded in Spurr. Sections were taken via an ultramicrotome and post stained with uranyl acetate and lead citrate. Six to eight sections from each animal were examined in a Phillips 201 electron microscope at $60 \mathrm{KV}$, with the examiner being blinded as to which sections were from control or smoke-exposed animals.

\section{Results}

\subsection{Perinatal findings}

Carboxyhemoglobin levels were performed on the eighteenth day of gestation in two pregnant smoke-exposed mice, and both yielded a value of $9.0 \%$. These levels were drawn after two episodes of smoke exposure on that day and just before the third episode. The amount of feed ingested per animal during the gestational period did not differ between the two groups. Litter size was not significantly different between the smoke-exposed and control animals, 5.09 and 4.73 respectively. There were a total of 61 pups born in 14 litters in the smokeexposed group and a total of 57 pups born in 12 litters in the control group. The mean birth weight was slightly but significantly smaller in the 16 smoke-exposed pups that were weighed 
$(1.3014 \pm 0.0552 \mathrm{gm})$ vs. the 54 control pups $(1.3620 \pm 0.1141) \quad(p<0.05)$. The smokeexposed pups tended to be killed soon after birth by the older mice in the cage. Newborn pups that were present and alive in the smoking cage would be killed soon after the onset of exposing them to smoke. Pups that were born during a smoking period were killed almost immediately. However instead of being eaten after being killed as is usually the case with dead mouse pups, they were just left. This fact along with the use of some of the smoke-exposed pups for other studies accounted for the smaller number of pups being weighed in the smoke-exposed group as compared to the control group.

\subsection{Ultrastructural findings}

Control group: In the peripheral blood vessels in these fetuses, the endothelial surface was relatively smooth, containing only the usual small pinocytotic vacuoles, normal length marginal folds, and occasional fingerlike protrusions of the cytoplasm into the vascular lumen (figures 2-4). The mitochondria and endo-

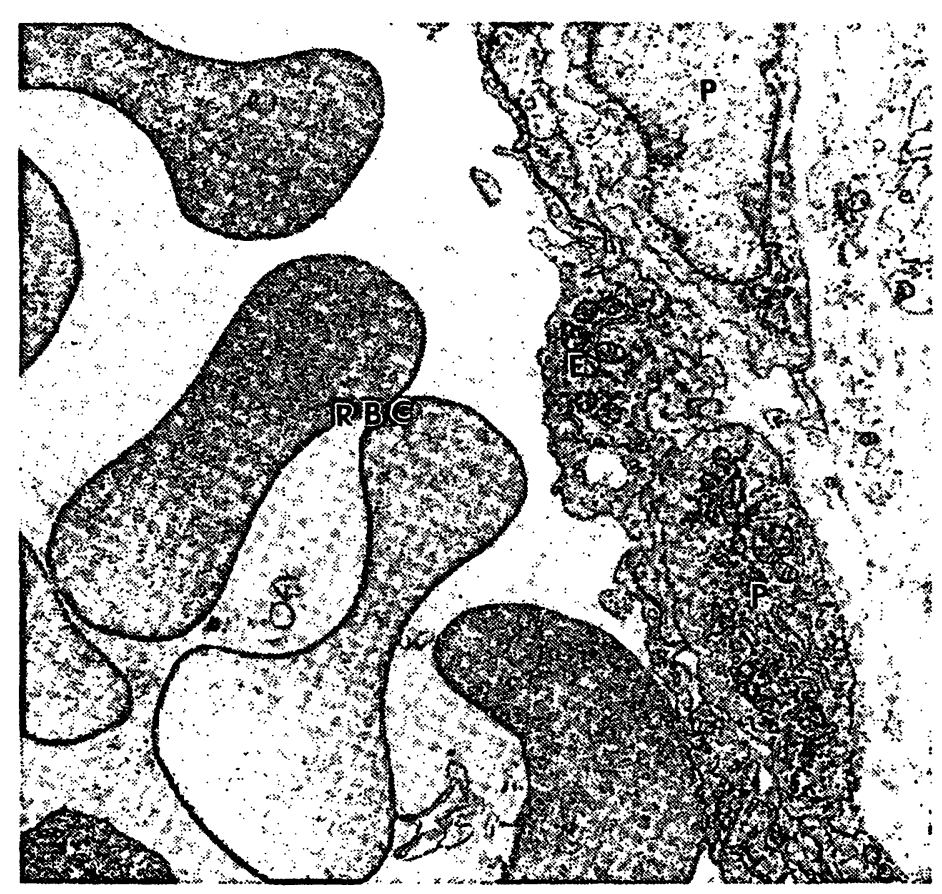

Figure 2. An arteriole from a control fetus with relatively smooth luminal surface of the endothelial cell (E). Red blood cells (RBC) and two pericytes (P) are visible. MAG 7194.

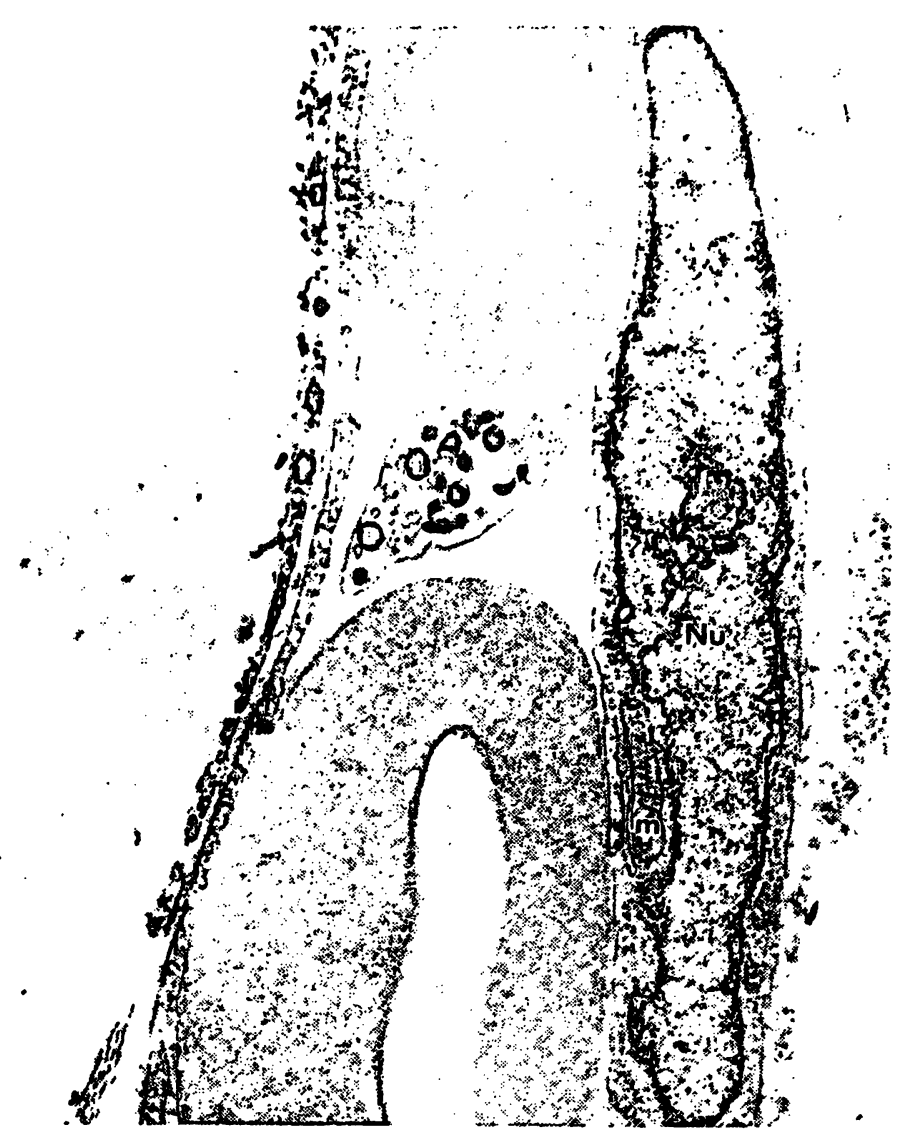

Figure 3. A capillary from a normal fetus with smooth luminal borders and normal thin cytoplasm. An endothelial nucleus $(\mathrm{Nu})$ and mitochondria $(\mathrm{M})$ are visible. MAG 10,572.

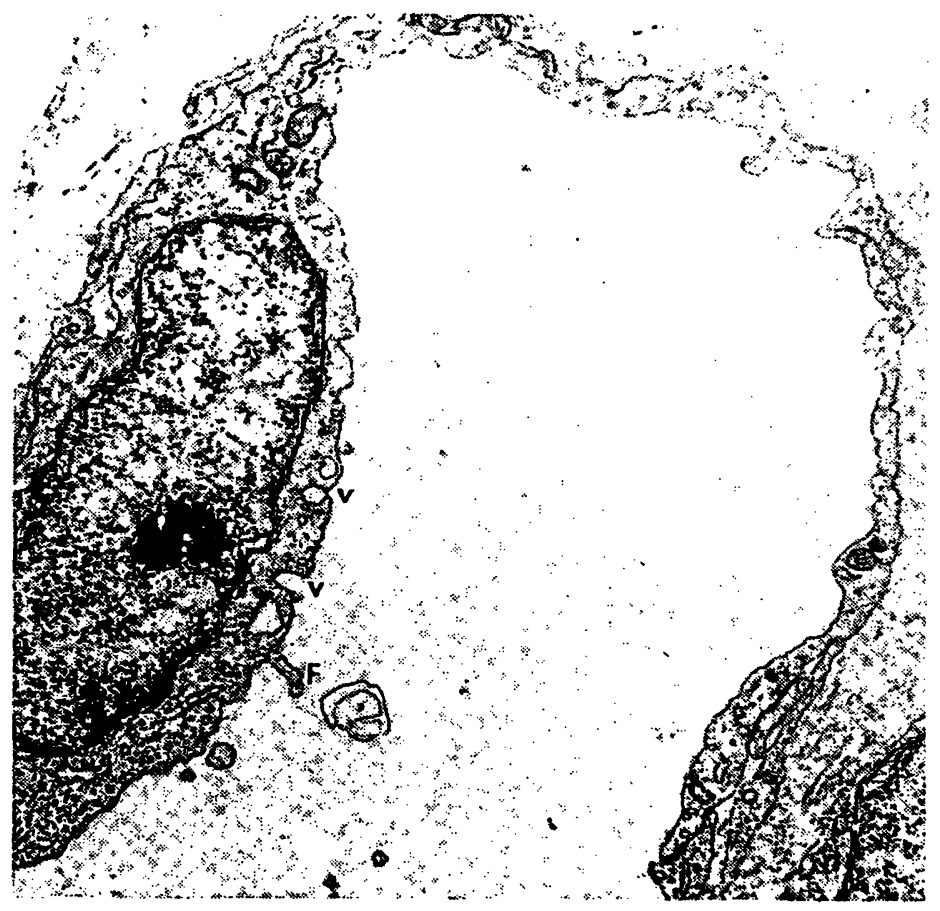

Figure 4. A small vessel from a control fetus with a smooth endothelial luminal border containing pinocytotoc vessels (V) and a fingerlike cytoplasmic protrusion into the vascular lumen (F). MAG 10,572. 
plasmic reticulum were histologically normal (figures 2 and 4).

Smoke-exposed group: The blood vessels from fetuses whose mothers were exposed to smoke were markedly abnormal. The most striking finding was the appearance of endothelial vacuoles located in the substance of the cytoplasm (figures 5-7). These blister-like vesicles have been termed vacuole-type endothelial blebs. These blebs were found in the vessels of all six animals, but not in every vessel on each section, and were more prominent in the arterioles than in the venules or capillaries.

A less striking finding, but one noted in most every vessel on each section of all six animals, was the appearance of surface-type blebs (figures 7 and 8). These blebs can be very similar to the fingerlike protrusions into the lumen found in the controls except that the distal end was always more dilated than the proximal portion. This dilation of the distal end varied greatly from a small dilation containing only cytoplasm (figure 7) to a large dilation with vacuolization (figure 8 ).

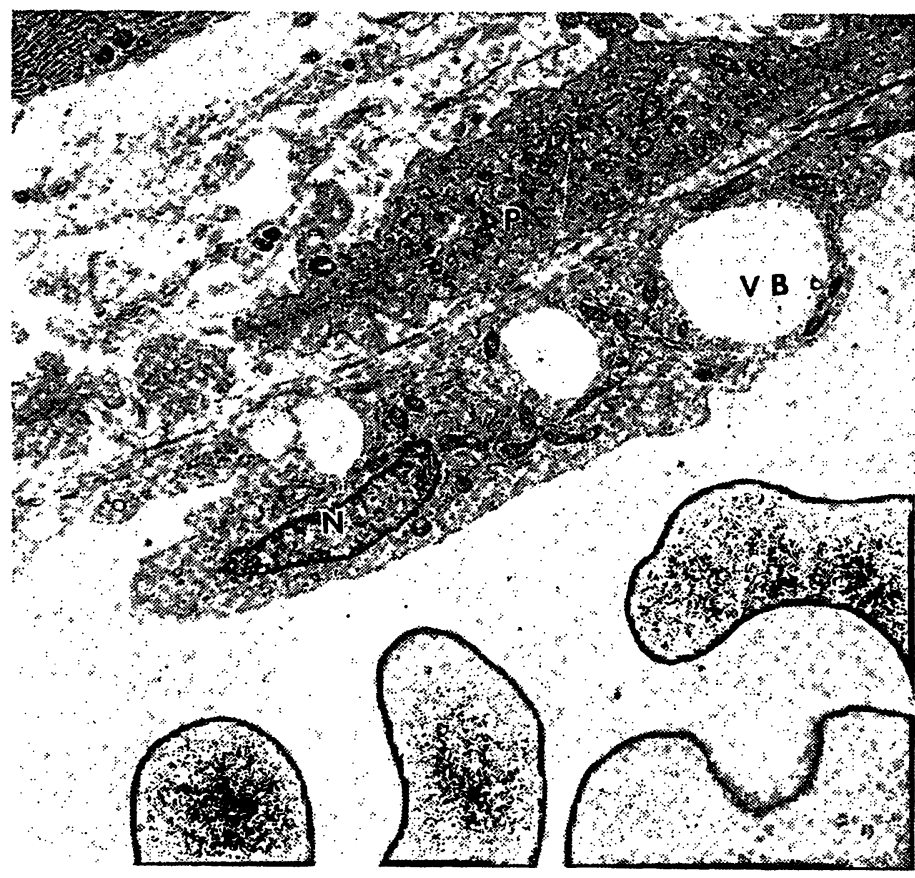

Figure 5. An arteriole from a fetus whose mother was exposed to smoke showing vacuole-type endothelial blebs (VB), a pericyte (P), and an endothelial nucleus (N). MAG 7194.
The least common finding was the appearance of dilated endoplasmic reticulum in the endothelium (figure 9). This was found in only three of the six animals and in only a few of the capillaries from these three. Thickened basal lamina and collagen changes were not demonstrable in any vessels from any animal.

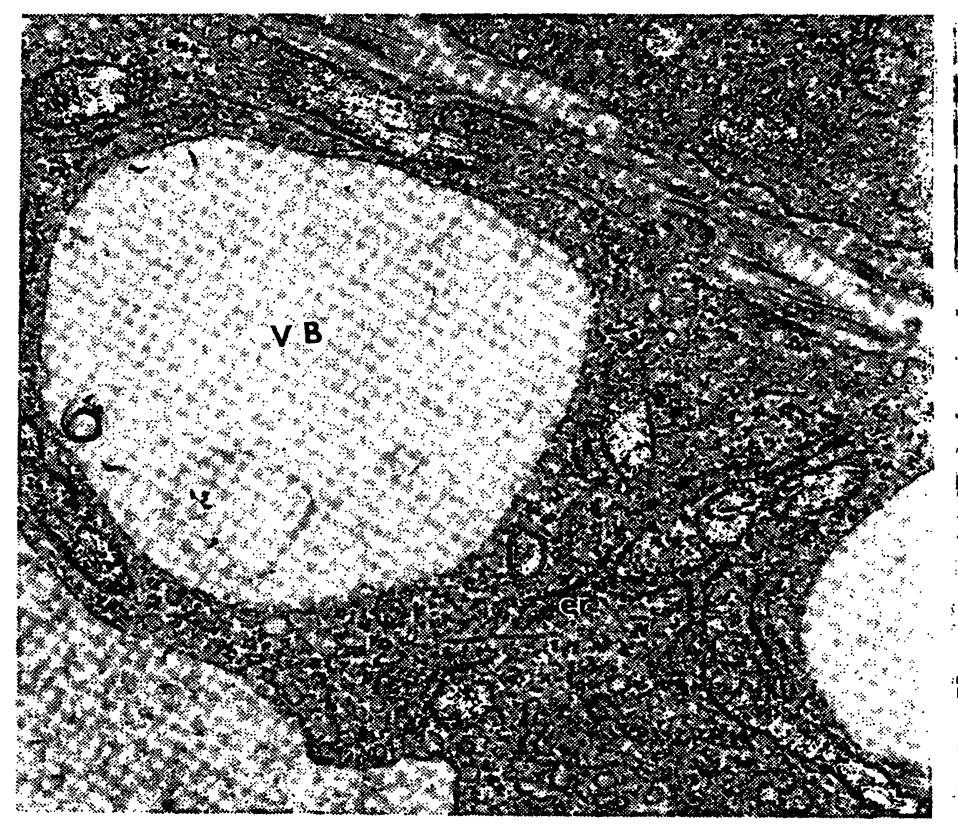

Figure 6. A close up of figure 4 with vacuole-type endothelial blebs (VB) and normal endoplasmic reticulum (ER). MAG 23,217.

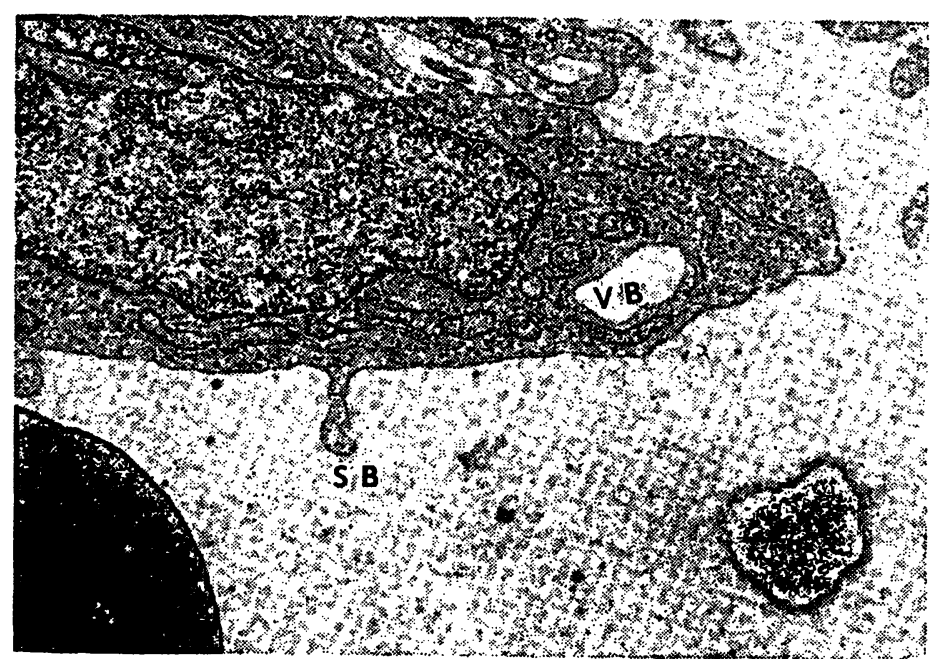

Figure 7. An arteriole from a study fetus showing a vacuole-type endothelial bleb (VB) and a surface-type bleb (SB) that is finger-like but having a dilated distal portion. MAG 10,572. 
Strict attention to gender was not taken during this study. However, on review of the data it was noted that in the last litter of both the smoke-exposed and control groups, gender was

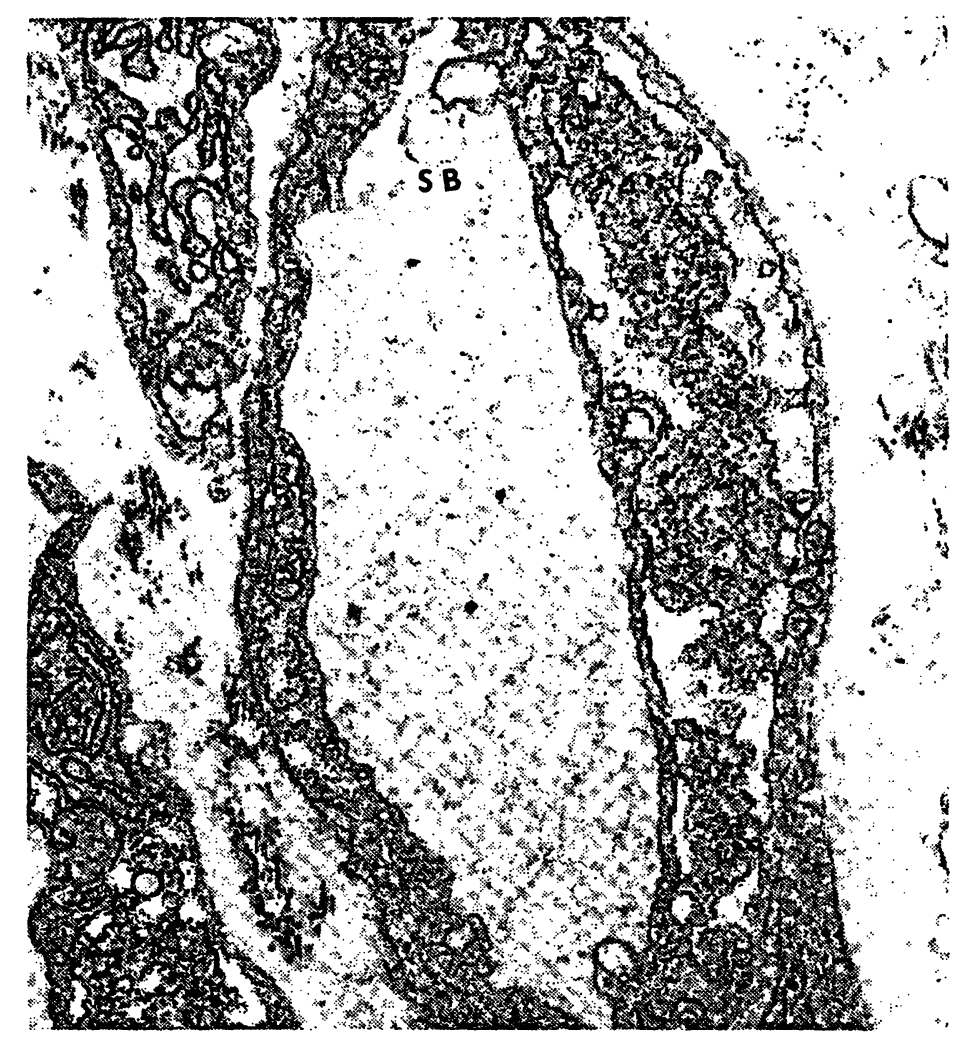

Figure 8. A capillary from a study animal with surfacetype blebs (SB) that are vesicular in the distal portion. MAG 10,572.

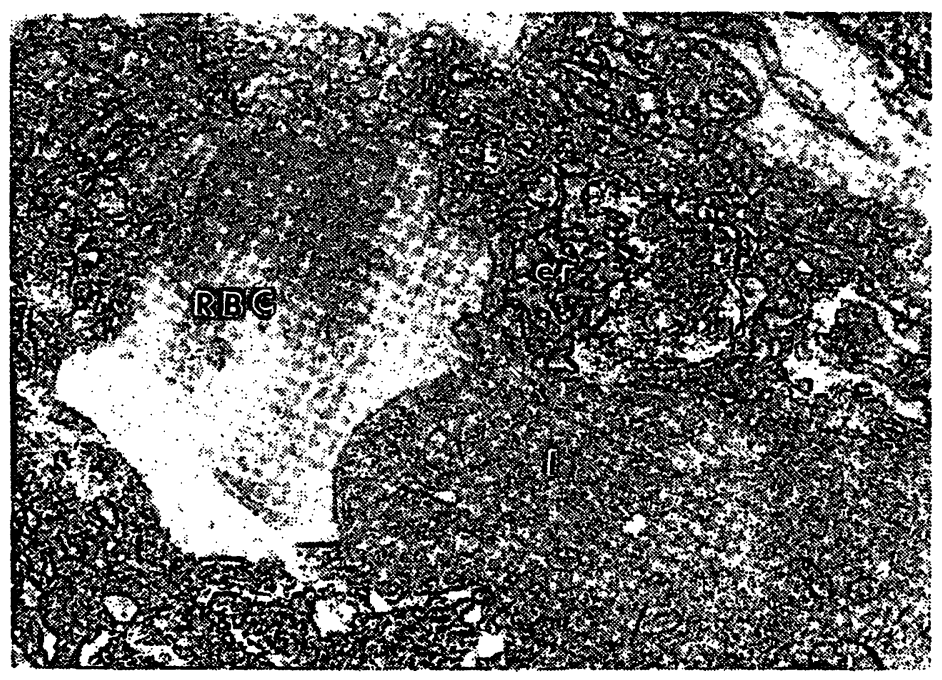

Figure 9. An arteriole from a smoke-exposed fetus with dilated endoplasmic reticulum (ER) in the endothelium. Mature red blood cells (RBC) and an immature red blood cell (I) are visible within the lumen. MAG 7194. assigned and one male and one female pup were taken for study in each of the litters. Both the female and male pups of the smoke-exposed group had surface and vacuole type blebs and neither had dilated endoplasmic reticulum.

\section{Discussion}

Sub-endothelial blebs have been found in the aortas of adult rats exposed to cigarette smoke and in adult rabbit aortas exposed to carbon monoxide [8, 11]. Similar blebs have been described as present in umbilical veins in humans whose mothers smoked [3]. These have been thought to be secondary to edema or to macrophage degeneration $[3,8,11]$. The vacuole-type endothelial blebs described in this paper appear very similar to the sub-endothelial blebs except that they are located within the endothelial cytoplasm. The location of the blebs within and not below the cytoplasm may be the difference in the response of fetal tissue versus adult tissue, or it may represent an earlier stage of the same process. It could be expected that fetal tissue may respond differently than adult tissue because the fetal tissue is undergoing a differentiation process while it is being exposed to the toxic substances, and the blood levels of the toxic substances in the fetus may be very different from those in the mother [13]. However, the vesicles found in our study are so similar to previously described blebs that the possibility of their representing a different time period of the same process is very plausible.

Focal areas of "ruffled" endothelium, areas with numerous cytoplasmic projections, have been found in the aortic arches of rabbits exposed to nicotine [7]. Actual blebbing, where the neck of the projection is much smaller than the distal portion, has been found in the placental and umbilical vessels of human fetuses whose mothers smoked during pregnancy [ 1 , $2,4,5]$. The surface-type blebbing found in this study varied greatly in appearance and was, in the one extreme, similar to that found in the ruffled area and, in the other extreme, similar to that found in the placental and umbilical 
vessels. The variability of the surface blebbing may represent different time periods of the same process. The blebs that have vacuoles may be the end stage as these were the type seen in human studies during which fetuses were exposed to the toxin 270 days. The club shaped blebs may be the earlier stage as these are similar to the cytoplasmic projections found in adult rat aortas in studies exposing rats to nicotine for about half of that time. Another explanation for the variability is that the mouse fetal endothelium is responding to the nicotine with excessive numbers of cytoplasmic projections, and the swelling of the distal portion is caused by other toxic products of smoking such as carbon monoxide [6].

Dilated endoplasmic reticulum has been found in umbilical arteries of human fetuses whose mothers smoked during pregnancy $[1,4]$. Because this finding has only been noted in fetuses and not in adults, dilated endoplasmic reticulum of the endothelium may be a response to smoking that is limited to fetal tissue. This may be due to the difference in blood levels, metabolic processes, or maturity of the cells.

The smaller mean weight of the smoke-exposed pups is to be expected as this finding is consistently present in human studies of smoking in pregnancy [10]. Since the feed consumption, the amount of handling, and the housing conditions of the smoke-exposed group and the controls were the same, it is very difficult to attribute the weight differences to these factors.
Therefore, the vascular changes seen in the fetuses of smoke exposed mothers may possibly be related to the weight difference. One can theorize that the vascular changes may affect the transendothelial transfer of nutrients and metabolites, thus interfering with maximal fetal growth [12].

Sex-related differences in the fetal development of other tissues have been reported [14]. In this study gender assignment was not given in all the subjects, therefore, some of the changes seen may be due to developmental differences in the sexes. However, the finding of both types of blebs in both the female and the male smokeexposed pups suggests that these changes are not sex-related. Since the dilated endoplasmic reticulum was seen in smoke-exposed animals where gender was not assigned, the effect of sex-related developmental differences causing the changes rather than the smoke exposure is up to question.

In all previous smoking-related fetal studies, the vessels (placental and umbilical) that were examined for pathologic changes were those that were initially exposed to the noxious stimuli $[1-5]$. In this study, similar pathologic ultrastructural changes were found in fetal vessels far removed from the point of noxious transfer. This tends to support the concept that smoking during pregnancy not only affects the fetus in utero and perinatally but may initiate processes that make it more susceptible to diseases in later life $[2,4]$.

\section{Summary}

Ultrastructural changes have been found in umbilical blood vessels, placental blood vessels, and peripheral blood vessels of human fetuses whose mothers smoked during pregnancy. This study was undertaken to determine if similar changes could be found in peripheral blood vessels of mice fetuses whose mothers were exposed to cigarette smoke during pregnancy.

Breeding mice of the C57BL/KsJ strain were placed in a smoking box similar to that described by YounOsZAI [12] and exposed to cigarette smoke intermittently. This produces carbon monoxide levels in the adult mice similar to that found in human adults smoking one pack of cigarettes per day. Similarly caged mice of the same strain were used as controls. The female mice were not removed from their cage from pre-conception time until after delivery. Upon delivery each pup was sacrificed via neck fracture and the entire pup was immersed in a solution of $2.5 \%$ gluteraldehyde in $0.1 \mathrm{M}$ cacodylate buffer at $\mathrm{pH}$ 7.3. While still under solution, the rear leg muscles were dissected free, sliced, and immersed in the same preservative for four to five hours. They were then placed in fresh $2.5 \%$ gluteraldehyde mixture overnight. The tissues were post-fixed in osmium ferrocyanide and en-block stained with uranyl acetate in a graded series 
of alcohol. The tissues were infiltrated with and embedded in Spurr. Sections were taken via an ultramicrotome and post-stained with uranyl acetate and lead citrate. The sections were examined in a Philips 201 electron microscope at $60 \mathrm{KV}$.

In the peripheral vessels of the fetuses from smokeexposed mothers, endothelial blebbing (both surfacetype and vacuole-type) was seen. In addition, dilated rough endoplasmic reticulum was found in these vessels. These findings were not demonstrable in the control fetuses. Surface-type blebs, dilated RER, thickened basal lamina, and collagen changes have been found in the umbilical blood vessels of human fetuses whose mothers smoked during pregnancy. Vacuole-type endothelial blebs have been seen in the aortas of adult rats exposed to cigarette smoke. Carbon monoxide exposure alone has produced similar vacuole-type endothelial blebs in the rat aorta. In all of the previous fetal studies the vascular changes were seen in vessels (umbilical and placental vessels) that initially received the blood that was exposed to noxious effects of cigarette smoking. This is the first known report of finding changes in vessels far removed from the point of noxious transfer in fetuses and tends to support the concept that smoking during pregnancy not only affects the fetus in utero and perinatally but may initiate processes that make it more susceptible to diseases in later life.

Keywords: Arteries, blood vessels, carbon monoxide, cigarette, electron microscopy, fetal morphology, maternal, passive smoking, toxic effects, ultrastructural abnormalities.

\section{Zusammenfassung}

EinfluB maternaler Zigarettenrauchexposition auf die Ultrastruktur fetaler, peripherer Blutgefäße bei der Maus Bei Feten, deren Mütter in der Schwangerschaft rauchten, wurden ultrastrukturelle Veränderungen an den Umbilikalgefäßen, den plazentaren Gefäßen sowie den peripheren Blutgefäßen gefunden. Ziel dieser Studie war festzustellen, ob bei Mäusefeten, deren Muttertiere Zigarettenrauch ausgesetzt waren, ähnliche Veränderungen an den peripheren Blutgefäßen zu beobachten waren. Trächtige Mäuse eines bestimmten Stamms (C57BL/ $\mathrm{KsJ}$ ) wurden in eine Raucherbox gesetzt (ähnlich wie bei YounOsZaI [12] beschrieben) und intermittierend Zigarettenrauch ausgesetzt. Der Kohlenmonoxydspiegel bei den adulten Mäusen war vergleichbar mit den Spiegeln bei Erwachsenen, die pro Tag eine Schachtel Zigaretten rauchen. Als Kontrollen wurden Mäuse der gleichen Zellinie benutzt, die in ähnlichen Käfigen untergebracht waren. Die weiblichen Mäuse blieben in den Käfigen von der Zeit vor der Konzeption bis nach dem Werfen. Dann wurden die jungen Mäuse durch Fraktur der Halswirbelsäule getötet und der gesamte Wurf in eine Lösung aus 2,5\%igem Gluteraldehyd in 0.1 molarem Cacodylat-Puffer mit einem pH von 7.3 gebracht. Noch in der Lösung wurden die Muskeln der hinteren Extremitäten freigelegt, Schnitte angelegt und in der gleichen Lösung für 4-5 Stunden belassen. Danach wurden sie in einer frischen $2,5 \%$ igen Gluteraldehydlösung über Nacht aufbewahrt. Das Gewebe wurde in Osmium-Ferrocyanid fixiert und en bloque mit Uranylacetat in Alkoholbädern abgestufter Konzentration gefärbt. Nach Einbettung wurden mit einem Ultramikrotom Schnitte angelegt sowie eine Nachfärbung mit Uranylacetat und
Bleicitrat vorgenommen. Die Schnitte wurden mit dem Philips-201-Elektronenmikroskop bei $60 \mathrm{kV}$ ausgewertet.

In den peripheren Gefäßen von Feten, deren Muttertiere rauchexponiert waren, zeigten sich endotheliale Aufblähungen sowohl vom Oberflächentyp wie auch vom Vakuolentyp. Zusätzlich war in diesen Gefäßen das rauhe endoplasmatische Retikulum (RER) dilatiert. Bei den Kontrolltieren fanden sich solche Veränderungen nicht. Oberflächenaufblähungen, dilatiertes RER, verdickte Basallamina und Kollagenveränderungen wurden in Umbilikalgefäßen von menschlichen Feten, deren Mütter während der Schwangerschaft geraucht hatten, beschrieben. Bei rauchexponierten adulten Ratten wurden in der Aorta endotheliale Aufblähungen vom Vakuolentyp beobachtet. Wurden die Ratten ausschließlich Kohlenmonoxyd ausgesetzt, entstanden in der Aorta vergleichbare endotheliale Aufblähungen vom Vakuolentyp. In allen vorangegangenen Untersuchungen an Feten wurden vaskuläre Veränderungen in umbilikalen und plazentaren Gefäßen beschrieben, also dort, wo der erste Kontakt mit dem Blut, das der Noxe Zigarettenrauch ausgesetzt war, stattfindet. In der vorliegenden Studie werden zum ersten Mal Veränderungen an peripheren Gefäßen erfaßt, also nicht nur dort, wo der Transfer der Noxe erfolgt. Hiermit wird die Hypothese unterstützt, $\mathrm{da} B$ Rauchen in der Schwangerschaft nicht nur den Feten in utero beeinträchtigt und perinatale Auswirkungen hat. Vielmehr können Prozesse initiiert werden, die mit einer erhöhten Morbidität im späteren Leben einhergehen.

Schlüsselwörter: Arterien, Blutgefäße, Elektronenmikroskopie, fetale Morphologie, Kohlenmonoxyd, mütterliche Morphologie, passives Rauchen, toxische Effekte, ultrastrukturelle Anomalien, Zigaretten. 


\section{Résumé}

Effet de l'exposition au tabagisme maternel sur l'ultrastructure des vaisseaux sanguins périphériques du foetus chez la souris

On a trouvé des modifications ultrastructurales au niveau des vaisseaux sanguins ombilicaux et des vaisseaux périphériques chez des fotus humains dont les mères fumaient pendant la grossesse. Cette étude a été entreprise afin de determiner si l'on pouvait trouver des modifications similaires au niveau des vaisseaux périphériques de fœtus de souris dont les mères avaient été exposées à la fumée de cigarette pendant la gestation.

Des souris gestantes de la lignée C57BL/KsJ ont été placées dans une boîte «à fumée» similaire à celle décrite par Younoszaï [12] et ont été exposées par intermittence à la fumée de cigarette. Ce procédé entraîne des taux de monoxide de carbone chez les souris adultes similaires à ceux que l'on trouve chez les adultes humains qui fument un paquet de cigarettes par jour. Des souris de la même lignée, mises en cage de la même façon ont servi de contrôles. On n'a pas sorti les femelles de leur cage depuis le moment avant la conception jusqu'après l'accouchement. Lors de la naissance, chaque souriceau a été sacrifié par fracture cervicale et le souriceau entier était plongé dans une solution de gluteraldéhyde à $2,5 \%$ avec un tampon de cacodylate $0,1 \mathrm{M}$ à $\mathrm{pH} 7,3$. Les muscles de la patte arrière étaient disséqués toujours dans la solution, puis on les découpait et on les plongeait dans la même solution conservatrice pendant quatre à cinq heures. Les muscles étaient ensuite placés dans une solution fraîche de gluteraldehyde à $2,5 \%$ pendant toute une nuit. Les tissus étaient ensuite post-fixés avec un ferrocyanide osmium et colorés en bloc par l'acétate d'uranyl. Les tissus s'infiltraient et l'inclusion se réalisait. On réalisait des coupes à l'aide d'un ultra-microtome et une post-coloration était effectuée avec de l'uranyl acetate et du citrate de plomb. Les coupes ont été examinées à l'aide d'un microscope électroniqe Philips 201 à $60 \mathrm{KV}$. Dans les vaisseaux périphériques des fotus, provenant de mères exposées à la fumée, on voit des bulles endothéliales (de deux types: de surface et vacuolaire). En outre, on trouve dans ces vaisseaux une dilatation du reticulum endoplasmique rugueux. Ces éléments n'ont pas été retrouvés chez les fœetus contrôles. On a trouvé dans les vaisseaux ombilicaux de fotus humains dont les mères avaient fumé pendant la grossesse, des bulles de surface, un RER dilaté, un épaississement de la lame basale, et des modifications du collagène. On a observé des bulles endothéliales de type vacuolaire au niveau de l'aorte de rats adultes exposés à la fumée de cigarette. L'exposition au monoxyde de carbone seul entraine des bulles endothéliales similaires de type vacuolaire au niveau de l'aorte de rat. Dans toutes les études fotales antérieures, les modifications vasculaires ont été observées au niveau des vaisseaux (vaisseaux ombilicaux et placentaires) qui reçoivent en premier le sang qui a été exposé aux effets nocifs de la fumée de cigarettes. Ce rapport est le premier connu a avoir trouvé des modifications au niveau de vaisseaux très éloignés du point transfer nocif chez les foetus et ce rapport tend à appuyer le concept que le tabagisme au cours de la grossesse n'affecte pas seulement le fotus in utero et en période périnatale mais qu'il peut initier des processus qui pourront le rendre plus sujet à certaines maladies au cours de sa vie ultérieure.

Mots-clés: Anomalies ultrastructurales, artères, cigarettes, effets toxiques, fumeur passif, maternel, microscope électronique, monoxyde carbone, morphologie fœtale, vaisseaux sanguins.

\section{References}

[1] ASMUSSEN I, K KJELDSEN: Intimal ultrastructure of human umbilical arteries. Circ Res 36 (1975) 579

[2] ASMUSSEN I: Ultrastructure of the human placenta at term. Acta Obstet Gynecol Scand 56 (1977) 119

[3] ASMusSEN I: Ultrastructure of human umbilical veins. Acta Obstet Gynecol Scand 57 (1978) 253

[4] ASMussen I: Arterial changes in infants of smoking mothers. Postgrad Med J 14 (1978) 200

[5] Asmussen I: Ultrastructure of the villi and fetal capillaries in placentas from smoking and nonsmoking mothers. Br J Obstet Gynaecol 87 (1980) 239

[6] AstruP P, K KJeldSEn: Model studies linking carbon monoxide and/or nicotine to arteriosclerosis and cardiovascular disease. Prev Med 8 (1979) 295
[7] Booyse FM, G OsIKowICZ, AJ QuARFoot: Effects of chronic oral consumption of nicotine on the rabbit aortic endothelium. Am J Pathol 102 (1981) $2 f 29$

[8] Boutet M, M Bazin, H Turcotte, R Lagace: Effects of cigarette smoke on rat thoracic aorta. Artery 7 (1980) 56

[9] Bylock A, G Bondjers, I Jansson, HA Hansson: Surface ultrastructure of human arteries with special reference to the effects of smoking. Acta Path Microbiol Scand 87 (1979) 201

[10] JENKINS JH: Smoking during pregnancy - A review of the literature. In: Bulletin of the Department of Gynecology and Obstetrics and Affiliated Institutions (III) 1 (1981) 9. The Woodruff Medical Center, Emory University School of Medicine 
[11] KJEL.DSEN K, P Astriup, J WANSTRUP: Ultrastructural intimal changes in the rabbit aorta after a moderate carbon monoxide expose. Atherosclerosis 16 (1972) 67

[12] Younoszai MK, J Peloso, JC Haworth: Fetal growth retardation in rats exposed to cigarette smoke during pregnancy. Am J Obstet Gynecol 104 (8) (1969) 1207

[13] Wang IY, RE Rasmussen, R Crrasey, TT CrockBR: Metabolites of benzo(a) pyrene produced by placental microsomes from cigarette smokers and nonsmokers. Life Sci 20 (1977) 1265
[14] Adamson IYR, GM KuNG: Sex differences in the development of fetal rat lung Part II. Quantitative morphology of epithelial-mesochyme intcractions. Lab Invest 50 (1984) 461

Reccived January 15, 1985. Revised July 25, 1985. Accepted September 30, 1985.

Robert C. Kaufmann, M. D.

Assistant Professor,

Division of Maternal/Fetal Medicine,

Department of Obstetrics and Gynecology

Southern Illinois University School of Medicinc P. O. Box 3926

Springfield, IL 62708, U. S. A. 